\title{
DIREITO À NÃO-VIOLÊNCIA OBSTÉTRICA E O CONTEXTO DA AÇÃO CIVIL PÚBLICA N 1005413-82.2018.4.01.3200
}

\author{
RIGHT TO OBSTETRIC NO-VIOLENCE AND THE CONTEXT OF PUBLIC CIVIL \\ ACTION No 1005413-82.2018.4.01.3200
}

Valmôr Scott Junior ${ }^{1}$

Karina Gularte Peres ${ }^{2}$

\section{RESUMO}

A violência contra a mulher prejudica o acesso a direitos humanos e liberdades fundamentais. Neste cenário, o presente estudo busca refletir sobre a utilização dos processos coletivos no enfrentamento da violência obstétrica, por meio da observação de ação civil pública $\mathrm{n}^{\circ}$ 1005413-82.2018.4.01.3200, proposta em face da União e do Estado do Amazonas, em 2018. Para tanto, inicialmente, será apresentada a trajetória histórica do enfrentamento da violência contra a mulher, bem como a abrangência da temática. Em seguida, discorre-se, especificamente, sobre a violência obstétrica, inclusive, mencionando debates atuais sobre este problemática. Por fim, realiza-se a leitura da peça inicial da ação civil pública para o combate da violência obstétrica. Trata-se de petição inicial da ação promovida pelo Ministério Público Federal (MPF), juntamente com o Ministério Público do Amazonas (MP/AM). Tal escolha justifica-se pela robusta fundamentação, adequada aos fins pretendidos para este estudo. Ainda, com a colaboração de fundamentos apontados por estudiosos como MORIN (2015), PASINATO (2011), entre outros, busca-se promover a reflexão sobre a pertinência dos processos coletivos no tratamento da violência obstétrica, como forma de violência contra a mulher. O método utilizado consiste na análise documental em jurisprudência.

\footnotetext{
${ }^{1}$ Professor Adjunto na faculdade de Direito, da Universidade Federal de Pelotas/ UFPel; Professor Permanente no Mestrado em Direito - PPGD/UFPel, na Linha de Pesquisa 2 - Direito e Vulnerabilidade Social, em temáticas que relacionam Direito, Educação e Vulnerabilidade. Doutor em Educação/UFSM; Mestre em Educação/UFSM; Especialista em Direito/UFSM; com graduação em Direito/UNICRUZ, Licenciatura - PEG/UFSM. Coordenador do GEDEV - Grupo de Estudo sobre Direito, Educação e Vulnerabilidade; Membro pesquisador no NUPEDIV Núcleo de Pesquisas em Direitos Sociais e Vulnerabilidade - UFPel; Membro pesquisador no RIZOMA - Políticas, Currículo e Educação - UFSM - Grupo de Pesquisa do CNPq; Membro pesquisador no Laboratório Imagens da Justiça - UFPel - Grupo de Pesquisa do CNPq. Membro do Conselho Editorial da Editora Caxias. Autor de livros, capítulos e artigos científicos publicados em revistas indexadas na área do Direito e da Educação; Parecerista em periódicos; Parecerista em comissão científica de eventos; Palestrante; Apresentador de comunicação oral em eventos nacionais e internacionais, com anais; autor de prefácios, entre outras atividades acadêmicas e administrativas; Interesse em pesquisas que articulem Direito e Educação, preferencialmente, com grupos em situação de vulnerabilidade social. E-mail: valmorscottjr@gmail.com

2 Mestranda do Programa de Pós-Graduação em Direito da Universidade Federal de Pelotas (2019-2021) e Assistente em Administração na mesma instituição desde 2015. Possui graduação em Direito pela Universidade Federal de Pelotas (2013-2018) e em Comunicação Social - Jornalismo pela Universidade Católica de Pelotas (2004-2009). Interrompeu graduação em Letras - Inglês pela Universidade Federal de Pelotas (2003-2007) e pósgraduação em Linguagens Verbais e Visuais e suas Tecnologias pelo Instituto Federal Sul-Riograndense (20112012).
} 


\title{
PALAVRAS-CHAVE:
}

Ação civil pública; violência contra a mulher; violência obstétrica.

\begin{abstract}
The violence against women undermines access to human rights and fundamental freedoms. In this scenario, the present study seeks to reflect on the use of collective processes in the confrontation of obstetric violence, through the observation of public civil action $\mathrm{n}^{\circ} 1005413$ 82.2018.4.01.3200 proposed in face of the Union and the State of Amazonas, in 2018. For this, purpose, it is initially presented the historical trajectory of confronting violence against women, as well as the scope of the theme. Then, it elaborates, specifically, about obstetric violence, including, mentioning current debates on this issue. Finally, the initial piece of public civil action to combat obstetric violence is read. This is the initial petition for the action promoted by the Federal Prosecution Service (MPF), together with the State Prosecution Service of Amazonas (MP/AM). Such choice is justified by the robust reasoning, adequate to the purposes intended by this study. Furthermore, with the collaboration of fundamentals pointed out by scholars, such as MORIN (2015), PASINATO (2011), among others, it seeks to promote reflection on the relevance of collective processes in the treatment of obstetric violence, as a form of violence against women. The method used consists of documental analysis is jurisprudence.
\end{abstract}

\section{KEYWORDS:}

Public civil action; violence against women; obstetric violence.

\section{INTRODUÇÃO}

O processo coletivo para defesa de interesses transindividuais como, por exemplo, a ação civil pública, liga-se, intimamente, com as particularidades da sociedade, da qual emergem diferentes classes de direitos e, de modo mais evidente, diferentes formas de violação. ${ }^{3}$ Como oriundo da massificação, estas lesões podem atingir direitos de vários titulares, simultaneamente, o que torna viável a busca conjunta por reparação e/ou indenização.

Estes direitos são considerados transindividuais, também, denominados supraindividuais ou, ainda, metaindividuais, porque sua violação não atinge, apenas e

\footnotetext{
${ }^{3}$ ARENHART, Sérgio Cruz; MARINONI, Luiz Guilherme; MITIDIERO, Daniel. Novo curso de processo civil: tutela dos direitos mediante procedimentos diferenciados. v. 3. 2. ed. São Paulo: Revista dos Tribunais, 2016. p. 403-404.
} 
individualmente, seu titular, mas toda categoria a qual aquele titular pertence. Exemplos podem ser encontrados na área do Direito ao Consumidor, uma vez que as ofensas verificadas são danosas, não apenas ao indivíduo envolvido no conflito, mas à posição de consumidor, ocupada por inúmeras pessoas a quem também interessa que não se admitam práticas lesivas.

Os direitos transindividuais podem ser classificados em subcategorias, sendo: direitos difusos, direitos coletivos stricto sensu e direitos individuais homogêneos. Os direitos difusos caracterizam-se pela impossibilidade ou inviabilidade de determinação de seus titulares, os quais se conectam por circunstâncias de fato. ${ }^{4}$ Diversamente, os direitos coletivos stricto sensu podem ter titulares determinados, já que estão ligados por circunstâncias de direito, entre si ou com a parte contrária. Por fim, os direitos individuais homogêneos ganham diferentes contornos porque atingem grande número de pessoas, de forma que o processo coletivo oferta eficiência e economia processual ao litígio. ${ }^{5}$

Neste cenário, destacam-se dois pontos no âmbito dos direitos transindividuais e processos coletivos: relevância da pretensão e acesso à justiça, sendo que o primeiro refere-se àqueles danos, aparentemente irrisórios, incapazes de levar o indivíduo lesado a buscar a tutela jurisdicional. A falta de interesse em judicializar o litígio justifica-se pelo desgaste que um processo judicial pode gerar, além da disponibilidade financeira e de tempo que a discussão em juízo exige. ${ }^{6}$ Estas circunstâncias traduzem impedimento ou, ao menos, maior dificuldade no acesso à justiça, o que demanda a intervenção dos órgãos legitimados, por meio de processo coletivo; isto porque os danos individualmente irrisórios, por afetarem inúmeros e distintos titulares, tornam-se significativos, o que justifica a intervenção judicial.

A ação civil pública é uma ferramenta que permite a busca por reparação nestes casos. Esse recurso, regulado pela Lei $\mathrm{n}^{\mathrm{o}} 7.347 / 1985$, destina-se à defesa de interesses difusos ou coletivos e pode ser proposta, apenas, pelos legitimados listados em seu art. $5^{\circ}$ : Ministério Público; Defensoria Pública; entes federativos; autarquia, empresa pública, fundação ou

\footnotetext{
${ }^{4}$ BRASIL. Lei $\mathrm{n}^{\circ}$ 8.078, de 11 de setembro de 1990. Dispõe sobre a proteção do consumidor e dá outras providências (Código de Defesa do Consumidor). Brasília: Presidência da República, 1990a. Disponível em: http://www.planalto.gov.br/ccivil_03/leis/18078.htm. Acesso em: 12 dez. 2019.

${ }^{5}$ BENJAMIN, Antônio Herman V. A insurreição da aldeia global contra o processo civil clássico. Apontamentos sobre a opressão e a libertação judiciais do meio ambiente e do consumidor. In: MILARÉ, Édis (coord.). Ação civil pública. Lei 7.347/85 - reminiscências e reflexões após dez anos de aplicação. São Paulo: Revista dos Tribunais, 1995. p. 95-96.

${ }^{6}$ Ibid., p. 108-109.
} 
sociedade de economia mista e, associação que esteja constituída há pelo menos um ano e que tenha por finalidade a proteção ao patrimônio público e social, ao meio ambiente, ao consumidor, à ordem econômica, à livre concorrência, aos direitos de grupos raciais, étnicos ou religiosos ou, ao patrimônio artístico, estético, histórico, turístico e paisagístico. ${ }^{7}$

Metodologicamente, trata-se de uma pesquisa qualitativa que tem, como método, a análise documental, sendo objeto de análise, uma ação civil pública $\mathrm{n}^{\circ}$ 100541382.2018.4.01.3200 proposta pelo Ministério Público Federal (MPF) e pelo Ministério Público do Estado do Amazonas (MP-AM) em face da União e do Estado do Amazonas, decorrente de inúmeras denúncias sobre práticas representativas de violência obstétrica em maternidades públicas deste estado.

Neste processo, para finalizar, o estudo de referências foi organizado da seguinte forma: $1^{\circ}$ ) apresentação de fatores sobre violência contra a mulher, em específico, a violência obstétrica; $2^{\circ}$ ) exposição de definições e contextualização da violência obstétrica na atualidade; $3^{\circ}$ ) discussão sobre a ação civil pública que constitui o objeto deste estudo, por meio da leitura exploratória de sua peça inicial, com ênfase para aspectos relevantes desta ferramenta representativa dos processos coletivos para o enfrentamento da violência obstétrica.

\section{VIOLÊNCIA CONTRA A MULHER: CONTEXTUALIZAÇÃO HISTÓRICA}

Os direitos das mulheres ainda urgem de defesa ostensiva, para além da garantia forma, em busca da garantia material. Entre tais direitos, está o direito à não-violência, especialmente importante, uma vez que a violência contra a mulher manifesta-se de várias formas. $\mathrm{O}$ art. $7^{\circ}$, da Lei $n^{\circ}$ 11.340/2006, denominada Lei Maria da Penha, define cinco modalidades exemplificativas de violência doméstica e familiar contra a mulher, sendo: (a) física: ofensa à integridade ou saúde corporal; (b) psicológica: condutas que resultem em dano emocional, diminuição da autoestima ou, impedimento de sua autodeterminação; (c) sexual: imposição

\footnotetext{
${ }^{7}$ BRASIL. Lei no 7.347 , de 24 de julho de 1985. Disciplina a ação civil pública de responsabilidade por danos causados ao meio ambiente, ao consumidor, a bens e direitos de valor artístico, estético, histórico, turístico e paisagístico (VETADO) e dá outras providências. Brasília: Presidência da República, 1985. Disponível em: http://www.planalto.gov.br/ccivil_03/Leis/L7347Compilada.htm. Acesso em: 13 dez. 2019.
} 
para presenciar ou manter relação sexual não desejada, indução em comercializar sua sexualidade ou, restrição a seus direitos sexuais e reprodutivos como, por exemplo, uso de método contraceptivo; (d) patrimonial: retenção, subtração e/ou destruição parcial ou total do que é de sua propriedade e; (e) moral: calúnia, difamação ou injúria. ${ }^{8}$

Atualmente, emergem outras formas de violência, associadas a contextos específicos, em decorrência de emergências e diversos outros fatores que operam na sociedade e que configuram violência contra a mulher. Atos de violência tendem a ter relação, entre outros elementos, com os papeis sociais atribuídos aos envolvidos no conflito. ${ }^{9}$ Diante disto, o tratamento da violência contra a mulher modifica-se no decorrer da história.

Assim, é necessário adotar uma perspectiva multidimensional para compreender o fenômeno ou, até mesmo, para criar novos questionamentos, assim como apresentar ferramentas potencialmente capazes de abrandar e/ou solucionar tais mazelas sociais. Isso significa que apenas poucos aspectos acerca da problemática não são capazes de prover, plenamente, este processo de conhecimento que, pela natureza, está em constante movimento. ${ }^{10}$ Entretanto, é possível verificar, na legislação e nas demandas judiciais, reflexos do exposto acima. Assim, surge a necessidade de apresentar apontamentos sobre a relação entre Estado e violência contra a mulher, demonstrados por meio de normativas internacionais.

Entre estes instrumentos, destaca-se a Convention on the Elimination of Discrimination against Women (CEDAW), de 1979. Embora, na esfera internacional, sejam encontradas normativas anteriores que preocupam-se com a promoção dos direitos das mulheres, a CEDAW pode ser considerada como marco inicial do enfretamento formal da violência contra a mulher na contemporaneidade, dada sua relevância. A Convenção é originária de comissão homônima da Organização das Nações Unidas (ONU) e, objetiva promover os direitos da mulher na luta pela igualdade de gênero, bem como combater a discriminação contra a mulher.

\footnotetext{
${ }^{8}$ BRASIL. Lei $n^{\circ} 11.340$, de 07 de agosto de 2006. Cria mecanismos para coibir a violência doméstica e familiar contra a mulher, nos termos do $\S 8^{\circ}$, do art. 226, da Constituição Federal, da Convenção sobre a Eliminação de Todas as Formas de Discriminação contra as Mulheres e da Convenção Interamericana para Prevenir, Punir e Erradicar a Violência contra a Mulher; dispõe sobre a criação dos Juizados de Violência Doméstica e Familiar contra a Mulher; altera o Código de Processo Penal, o Código Penal e a Lei de Execução Penal; e dá outras providências. Brasília: Presidência da República, 2006. Disponível em: http://www.planalto.gov.br/ccivil_03/leis/L9455.htm. Acesso em: 24 nov. 2019.

${ }^{9}$ PASINATO, Wânia. "Femicídios" e as mortes de mulheres no brasil. Cadernos Pagu, n. 37, p. 219-246, jul.-dez. 2011. Disponível em: https://www.scielo.br/pdf/cpa/n37/a08n37.pdf. Acesso em: 29 nov. 2019. p. 230.

${ }^{10}$ MORIN, Edgar. Introdução ao Pensamento Complexo. 5. ed. Porto Alegre: Sulina, 2015.
} 
O Brasil tornou-se signatário da Convenção sobre a Eliminação de Todas as Formas de Discriminação contra a Mulher, em 1984. ${ }^{11}$ Mais tarde, em 1994, foi realizada a Convenção Interamericana para Prevenir, Punir e Erradicar a Violência contra Mulher, denominada Convenção de Belém do Pará. Esta Convenção possui enfoque na violência contra a mulher e exige dos Estados signatários, a criação de meios para coibi-la. O Brasil tornou-se signatário em $1995 .^{12}$

A IV Conferência Mundial sobre a Mulher, realizada em Pequim, em 1995, reafirma que a violência contra a mulher prejudica o acesso a direitos humanos e liberdades fundamentais. Ainda, menciona como caso de violência contra a mulher, o prejuízo de seus direitos reprodutivos como, por exemplo, a gravidez, o aborto ou a esterilização forçados. A Declaração e Plataforma de Ação da IV Conferência Mundial Sobre a Mulher, ainda traz uma reflexão sobre as causas da violência, de acordo com a Convenção de Belém do Pará, conforme segue:

\begin{abstract}
A violência contra a mulher é uma manifestação das relações de poder historicamente desiguais entre mulheres e homens, que têm causado a dominação da mulher pelo homem, a discriminação contra ela e a interposição de obstáculos ao seu pleno desenvolvimento. A violência contra a mulher ao longo do seu ciclo vital deriva essencialmente de hábitos culturais, em particular dos efeitos prejudiciais de algumas práticas tradicionais ou consuetudinárias e de todos os atos de extremismo relacionados com raça, sexo, idioma ou religião, que perpetuam a condição de inferioridade conferida à mulher no seio da família, no local de trabalho, na comunidade e na sociedade. A violência contra a mulher é agravada por pressões sociais, como a vergonha de denunciar certos atos; [...] e pela ausência de meios educacionais e de outro tipo para combater as causas e as conseqüências da violência. As imagens de violência contra a mulher que aparecem nos meios de comunicação, em particular as representações de estupro ou de escravidão sexual, assim como a utilização de mulheres e meninas como objetos sexuais, inclusive a pornografia, são fatores que contribuem para a prevalência contínua dessa violência, prejudicial à comunidade em geral e, em particular, às crianças e aos jovens. ${ }^{13}$
\end{abstract}

Diante disto, o mesmo documento define três objetivos estratégicos relativos à prevenção e eliminação da violência contra a mulher, referentes às causas e consequências dessa

\footnotetext{
${ }^{11}$ BRASIL. Decreto ${ }^{\circ} 4.377$, de 13 de setembro de 2002. Promulga a Convenção sobre a Eliminação de Todas as Formas de Discriminação contra a Mulher, de 1979, e revoga o Decreto no 89.460, de 20 de março de 1984. Brasília: $\quad$ Presidência da $\quad$ República, $2002 . \quad$ Disponível http://www.planalto.gov.br/ccivil_03/decreto/2002/D4377.htm. Acesso em: 06 dez. 2019.

12 BRASIL. Decreto $n^{\circ} 1.973$, de 01 de agosto de 1996. Promulga a Convenção Interamericana para Prevenir, Punir e Erradicar a Violência contra a Mulher, concluída em Belém do Pará, em 9 de junho de 1994. Brasília: Presidência da República, 1996. Disponível em: http://www.planalto.gov.br/ccivil_03/decreto/1996/ D1973.htm. Acesso em: 06 dez. 2019.

13 ORGANIZAÇÃO DAS NAÇÕES UNIDAS (ONU). Declaração e Plataforma de Ação da IV Conferência Mundial Sobre a Mulher. Pequim, 1995. Disponível em: http://www.onumulheres.org.br/wpcontent/uploads/2015/03/declaracao_pequim1. pdf. Acesso em: 06 set. 2019. p. 190.
} 
violência e eficácia das medidas preventivas e; ao tráfico e prostituição de mulheres, com a apresentação de uma série de medidas relacionadas a serem adotadas pelos Estados. ${ }^{14}$

A Declaração do Milênio das Nações Unidas, resultado de conferência realizada em 2000, referenda, entre seus valores e princípios, o respeito pela igualdade de direito a todos, sem distinção por sexo ou outros fatores, assim como estabelece como meta: "promover a igualdade entre os sexos e a autonomia da mulher como meios eficazes de combater a pobreza, a fome e as doenças, além de promover um desenvolvimento verdadeiramente sustentável". ${ }^{15}$

A necessidade de cruzamento entre as categorias raça e gênero, ainda, demandada, é discutida, desde 2001, na III Conferência Mundial de Combate ao Racismo, Discriminação Racial, Xenofobia e Intolerância Correlata, em Durban. A Declaração e Programa de Ação referente a essa conferência menciona que os Estados precisam adotar uma perspectiva de gênero nas ações de combate ao racismo e à xenofobia, com o objetivo de que as mulheres vítimas de tais intolerâncias tenham efetiva igualdade de condições com os homens, em diversas áreas. $\mathrm{O}$ documento menciona casos específicos comuns a mulheres indígenas, migrantes e de ascendência africana ou asiática. Contudo, não é restritivo.

Os Estados têm o dever de proteger e promover os direitos humanos e as liberdades fundamentais de todas as vítimas, e que devem adotar uma perspectiva de gênero que reconheça as múltiplas formas de discriminação que podem afetar as mulheres e que o gozo de seus direitos civis, políticos, econômicos, sociais e culturais é essencial para o desenvolvimento das sociedades em todo o mundo. ${ }^{16}$

Em 2004, o Brasil ratificou o Protocolo Adicional à Convenção das Nações Unidas contra o Crime Organizado Transnacional Relativo à Prevenção, Repressão e Punição do Tráfico de Pessoas, em Especial Mulheres e Crianças, também, conhecido como Protocolo de

\footnotetext{
${ }^{14}$ Ibidem, p. 191-195.

15 ORGANIZAÇÃO DAS NAÇÕES UNIDAS (ONU). Declaração do Milênio. Nova Iorque, 2000. Disponível em: https://www.br.undp.org/content/brazil/pt/home/library/ods/declaracao-do-milenio.html. Acesso em: 20 mar. 2020.

${ }^{16}$ ORGANIZAÇÃO DOS ESTADOS AMERICANOS (OEA). Declaração e Programa de Ação adotados na III Conferência Mundial de Combate ao Racismo, Discriminação Racial, Xenofobia e Intolerância Correlata. Durban, $\quad 08 \quad$ set. $2001 . \quad$ Disponível em: https://www.oas.org/dil/port/2001\%20Declara\%C3\%A7\%C3\%A3o\%20e\%20Programa\%20de\%20A\%C3\%A7 $\% \mathrm{C} 3 \% \mathrm{~A} 3 \mathrm{o} \% 20$ adotado\%20pela\%20Terceira\%20Confer\%C3\%AAncia\%20Mundial\%20contra\%20o\%20Racis mo,\%20Discrimina\%C3\%A7\%C3\%A3o\%20Racial,\%20Xenofobia\%20e\%20Formas\%20Conexas\%20de\%20Int oler\%C3\%A2ncia.pdf. Acesso em: 20 mar. 2020.
} 
Palermo, o qual serve de instrumento contra o tráfico de pessoas, que vitimiza, costumeiramente, as mulheres. ${ }^{17}$

O protocolo orienta os Estados Partes sobre acolhimento, assistência e regresso da vítima ao país de origem, observado eventual risco de segurança que isto possa ocasionar. $\mathrm{O}$ tráfico de pessoas pode ser identificado como um tipo de violência, mesmo que este ato tenha finalidades diversas; destaca-se o tráfico de pessoas para fins de exploração sexual, que atinge, especialmente, mulheres.

O tráfico para fins de exploração sexual é uma das piores formas de violência
baseada em gênero [...] se sustenta em concepções patriarcais que, entre outros
mecanismos de manifestação, colocam as mulheres como objetos de consumo do
homem. Mulheres essas que em situação de tráfico são, em sua maioria, exploradas
para fins sexuais gerando ganhos milionários às redes que se dedicam a esse tipo de
exploração. ${ }^{18}$

Em 2005 foi promovida uma série de alterações no Código Penal, propostas pela Lei $\mathrm{n}^{\circ}$ 11.106/2005. A maioria dos dispositivos revogados estava presente no Título VI: Dos Crimes contra os Costumes e, o efeito dessa revogação ocasionou, entre outros fatores, a exclusão do tipo penal que tinha como elementar, a condição de mulher honesta, num claro pré-julgamento da vítima para o reconhecimento do delito. Nessa ocasião, o casamento da vítima de estupro com o agente deixou de extinguir a punibilidade do agressor. ${ }^{19}$

Possivelmente, 2006 marcou a mudança de maior destaque, pois foi promulgada a Lei Maria da Penha, Lei n ${ }^{\circ}$ 11.340/2006, que trata de violência doméstica e familiar contra a mulher. A inovação dessa Lei consiste, entre outros fatores, nos diversos conceitos que apresenta ao expor que a violência contra a mulher não se restringe à violência física, mas inclui a violência psicológica, patrimonial, entre outras, além de propor alterações que ultrapassam a punição ao agressor.

\footnotetext{
${ }^{17}$ BRASIL. Decreto ${ }^{\circ}$ 5.017, de 12 de março de 2004. Promulga o Protocolo Adicional à Convenção das Nações Unidas contra o Crime Organizado Transnacional Relativo à Prevenção, Repressão e Punição do Tráfico de Pessoas, em Especial Mulheres e Crianças. Brasília: Presidência da República, 2004. Disponível em: http://www.planalto.gov.br/ccivil_03/_Ato2004-2006/2004/Decreto/ D5017.htm. Acesso em: 06 dez. 2019.

${ }^{18}$ MERCOSUL. Guia Mercosul de atenção a mulheres em situação de tráfico de pessoas para fins de exploração sexual. dez. 2012. Disponível em: https://www.unodc.org/documents/human-trafficking/GLOACT/BR_Guia_MERCOSUL_Trafico_Mulheres_PORT_Completo_para_IMPRESSAO.pdf. Acesso em: 13 jan. 2020. p. 15-16.

${ }^{19}$ BRASIL. Decreto-Lei no 2.848, de 07 de dezembro de 1940. Código Penal. Rio de Janeiro: Presidência da República, 1940. Disponível em: http://www.planalto.gov.br/ccivil_03/decreto-lei/Del2848.htm. Acesso em: 24 nov. 2019.
} 
O Título VI, do Código Penal, passou por outra importante reforma em 2009, por força da Lei $n^{\circ}$ 12.015/2009, por meio da modificação de tal título para: Dos crimes contra a dignidade sexual e, foi ampliado o rol de condutas abrangidas pelo crime de estupro. ${ }^{20} \mathrm{~A}$ esse respeito, a Lei ${ }^{\circ}$ 12.845/2013 importou na obrigatoriedade do atendimento multidisciplinar às vítimas de violência sexual. ${ }^{21}$ No mesmo ano, por meio do Decreto $n^{\circ} 7.958 / 2013$, foram criadas diretrizes para esse atendimento. ${ }^{22}$

O Código Penal, em 2015, sofreu outra alteração no que tange à proteção da mulher; corresponde à tipificação do feminicídio como homicídio qualificado, com previsão expressa no art. $121, \S 2^{\circ}$, VI, do referido diploma legal. Essa alteração ocorreu por força da Lei $\mathrm{n}^{\circ}$ 13.104/2015 e buscou atender recomendação da ONU, mais especificamente, da Comissão sobre o Status da Mulher, segundo a qual os países deveriam reforçar sua legislação para punir assassinatos de mulheres por razão de gênero e implantar ações de prevenção. ${ }^{23}$

No ano anterior, em 2014, a Organização Mundial da Saúde (OMS) lançava documento para combater outra forma emergente de violência, a violência obstétrica, sendo que definições e apontamentos relacionados à violência obstétrica serão apresentados no próximo item.

\section{VIOLÊNCIA OBSTÉTRICA: DEFINIÇÃO E APONTAMENTOS}

Declaração da OMS, publicada em 2014, afirma que a violência obstétrica ocorre mudialmente. $\mathrm{O}$ documento caracteriza a violência obstétrica: abusos verbais, execução de procedimentos não consentidos e, detenção das mães e bebês devido a incapacidade de

\footnotetext{
20 Ibid.

${ }^{21}$ BRASIL. Lei $\mathrm{n}^{\circ} 12.845$, de 01 de agosto de 2013. Dispõe sobre o atendimento obrigatório e integral de pessoas em situação de violência sexual. Brasília: Presidência da República, 2013a. Disponível em: http://www.planalto.gov.br/ ccivil_03/_ato2011-2014/2013/lei/112845.htm. Acesso em: 21 set. 2019.

22 BRASIL. Decreto $\mathrm{n}^{\circ}$ 7.958, de 13 de março de 2013. Estabelece diretrizes para o atendimento às vítimas de violência sexual pelos profissionais de segurança pública e da rede de atendimento do Sistema Único de Saúde. Brasília: Presidência da República, 2013b. Disponível em: http://www.planalto.gov.br/ccivil_03/_ato20112014/2013/decreto/D7958.htm. Acesso em: 30 nov. 2019.

${ }^{23}$ BRASIL, 1940.
} 
pagamento dos serviços hospitalares. ${ }^{24}$ Outras situações, também, compõem ações danosas que configuram a violência obstétrica: falta de privacidade e negativa de medicamentos para dor às parturientes.

O primeiro caso verifica-se, por exemplo, na permissão de entrada e permanência de estranhos, frequentemente estudantes da área da saúde, durante o atendimento à mulher, sem seu consentimento, quando encontra-se em posição extremamente vulnerável (sobretudo fisicamente). O segundo pode ser, ainda, agravado, pois não apenas são relatadas situações em que analgésicos são negados, como também casos em que substâncias que aceleram o parto, porém intensificam a dor, são administrados sem solicitação ou consentimento da paciente. ${ }^{25}$

Tais situações, evidentemente, prejudicam a relação de confiança entre mulheres e equipes de $\operatorname{saúde}^{26} \mathrm{e}$, ainda, configuram violação do direito à maternidade. A violência obstétrica, principalmente no contexto do parto, tem base no estereótipo de gênero, colocando a mulher em posição de submissão e a presumindo frágil e incapaz de decidir por si. Esse tratamento inadequado agrava-se quando dirigido a parturientes de baixo nível socioeconômico. ${ }^{27}$

Pesquisa baseada em entrevistas com mais de duas mil brasileiras, realizada em 2010, apontou que $25 \%$ das participantes com filhos relataram ter sofrido algum tipo de violência durante o parto; admite-se a probabilidade de subdimensionamento e, ainda assim, esse resultado representa mais de 400 mulheres entrevistadas. ${ }^{28}$

Recentemente, o Ministério da Saúde publicou despacho ${ }^{29}$ com orientação à abolição do termo "violência obstétrica", sob a justificativa de que a OMS define violência como uma

\footnotetext{
${ }^{24}$ ORGANIZAÇÃO MUNDIAL DA SAÚDE (OMS). Prevenção e eliminação de abusos, desrespeito e maustratos durante o parto em instituições de saúde. 2014. Disponível em: https://apps.who.int/iris/bitstream/handle/10665/134588/ WHO_RHR_14.23_por.pdf. Acesso em: 21 nov. 2019.

${ }^{25}$ JARDIM, Danúbia Mariane Barbosa; MODENA, Celina Maria. A violência obstétrica no cotidiano assistencial e suas características. Revista Latino-Americana Enfermagem. 2018. v. 26. Disponível em: http://www.scielo.br/pdf/rlae/v26/pt_0104-1169-rlae-26-e3069.pdf. Acesso em: 12 nov. 2019. p. 2.

${ }^{26}$ ORGANIZAÇÃO MUNDIAL DA SAÚDE (OMS), loc. cit.

${ }^{27}$ JARDIM; MODENA, loc. cit.

${ }^{28}$ FUNDAÇÃO PERSEU ABRAMO (FPA); SERVIÇO SOCIAL DO COMÉRCIO (SESC). Mulheres brasileiras e gênero nos espaços público e privado. ago. 2010. Disponível em: https://fpabramo.org.br/publicacoes/wpcontent/uploads/sites/5/2017/05/pesquisaintegra_0.pdf. Acesso em: 21 nov. 2019.

${ }_{29}$ BRASIL. Ministério da Saúde. Secretaria de Atenção à Saúde. Despacho DAPES/SAS/MS em resposta a Ofício $n^{o}$ 017/2019 JUR/SEC. Brasil: Ministério da Saúde, 03 maio 2019. 2019a. Disponível em: https://sei.saude.gov.br/sei/controlador_externo.php?acao=documento_conferir\&codigo_verificador $=9087621 \&$ codigo_crc=1A6F34C4\&hash_download=c4c55cd95ede706d0b729845a5d6481d07e735f33d87d40984dd1b39a
} 
ação com dolo de dano. Essa espécie de dolo verifica-se quando há intenção do agente em produzir resultado material, opondo-se, principalmente, ao dolo de perigo, que ocorre quando a intenção do agente é expor o bem jurídico ofendido a risco. ${ }^{30} \mathrm{O}$ documento do Ministério da Saúde foi repudiado pela Ordem dos Advogados do Brasil (OAB), pela Associação Nacional dos Defensores Públicos Federais (ANADEF) e, pelo Ministério Público Federal (MPF), o qual respondeu com a Recomendação no 29/2010 31 .

Nesta Recomendação, o MPF afirma que diversas práticas relacionadas à violência obstétrica caracterizam violência contra a mulher, assim como não ser plausível reduzir o conceito de violência a ações com dolo de dano, pois exclui casos de dolo eventual, bem como crimes formais e crimes de mera conduta presentes no cenário da violência obstétrica.

O dolo eventual ou indireto verifica-se quando não há a intenção específica do agente em produzir o resultado, porém ele não se abstém de sua conduta, apesar do risco de produzilo. Trata-se não de vontade, mas de indiferença do agente em relação ao resultado. ${ }^{32}$

Quanto aos crimes formais, são aqueles em que apenas a conduta é suficiente para sua consumação, embora haja possibilidade de produzir resultado material concreto, o qual será, então, mero exaurimento. Os crimes de mera conduta, por sua vez, sequer têm previsão de resultado material, sendo considerados consumados na própria ação. Ambos se opõem aos crimes materiais, em que o resultado concreto é exigido para caracterizar a consumação. ${ }^{33}$ Diante disto, foi exigida manifestação do Ministério da Saúde que, por meio do Ofício $\mathrm{n}^{\circ}$ $296 / 2019^{34}$, reconhece às mulheres, o direito de usar o termo que melhor descreva sua experiência.

Em observação às proposições legislativas do Congresso Nacional, identificam-se algumas que tratam sobre a problemática, embora, nem sempre, tragam a expressão exata

\footnotetext{
32d870fe89dcf1014bc76a32d2a28d8f0a2c5ab928ff165c67d8219e35beb1a0adb3258\&visualizacao=1\&id_orgao _acesso_externo=0. Acesso em: 12 nov. 2019.

${ }^{30}$ GRECO, Rogério. Direito Penal Estruturado. Rio de Janeiro: Forense, 2019. p. 44.

31 MINISTÉRIO PÚBLICO FEDERAL (MPF). Recomendação no 29/2019. São Paulo (Estado): Ministério Público Federal, 07 maio 2019. Disponível em: http://www.mpf.mp.br/sp/sala-deimprensa/docs/recomendacao_ms_violencia_obstetrica.pdf. Acesso em: 12 nov. 2019.

${ }^{32}$ GRECO, op. cit., p. 43.

${ }^{33}$ Ibidem, p. 31.

34 BRASIL. Ministério da Saúde. Secretaria de Atenção Primária à Saúde. Ofício 296/2019/COSMU/CGCIVI/DAPES/SAPS/MS. Brasil: Ministério da Saúde, 07 jun. 2019. 2019b. Disponível em: http://www.mpf.mp.br/sp/sala-de-imprensa/docs/oficio-ms. Acesso em: 12 nov. 2019.
} 
“violência obstétrica”. Em 2017, a Deputada Federal Jô Moraes apresentou Projeto de Lei (PL) para estabelecer medidas de proteção contra a violência obstétrica. O PL nº 7.867/2017, define esse tipo de violência como: "todo ato praticado por membro da equipe de saúde, do hospital ou por terceiros, em desacordo com as normas regulamentadoras ou que ofenda, verbal ou fisicamente, as mulheres gestantes, parturientes ou puérperas" ${ }^{35}$ A proposição lista 21 condutas que configuram violência obstétrica.

No mesmo ano, o Deputado Federal Francisco Floriano apresentou o PL n $8.219 / 2017^{36}$, de teor semelhante ao PL $\mathrm{n}^{\mathrm{o}} 7.867 / 2017$. Por afinidade temática, ambos foram apensados à proposição anterior, o PL no 7.633/2014, de autoria do Deputado Federal Jean Wyllys. Essa proposição dispõe sobre a humanização da assistência à mulher e ao neonato, além de definir a violência obstétrica conforme segue:

Art. 13 - Caracteriza-se a violência obstétrica como a apropriação do corpo e dos processos reprodutivos das mulheres pelos(as) profissionais de saúde, através do tratamento desumanizado, abuso da medicalização e patologização dos processos naturais, que cause a perda da autonomia e capacidade das mulheres de decidir livremente sobre seus corpos e sua sexualidade, impactando negativamente na qualidade de vida das mulheres.

Parágrafo único. Para efeitos da presente Lei, considera-se violência obstétrica todo ato praticado pelo(a)profissional da equipe de saúde que ofenda, de forma verbal ou física, as mulheres gestantes em trabalho de parto, em situação de abortamento e no pós-parto/puerpério. ${ }^{37}$

Neste cenário, convém mencionar, também, o PL nº 6.888/2013, com foco na conscientização das gestantes e parturientes acerca de seu direito ao atendimento humanizado e de qualidade, para que possam exigir seu cumprimento. ${ }^{38}$ Recentemente, em 2019, foram apresentados outras proposições legislativas que tangenciam a violência obstétrica, as quais

\footnotetext{
35 BRASIL. Câmara dos Deputados. Projeto de Lei 7.867/2017. Dispõe sobre medidas de proteção contra a violência obstétrica e de divulgação de boas práticas para a atenção à gravidez, parto, nascimento, abortamento e puerpério. Brasília: Presidência da República, 2017a. Disponível em: https://www.camara.leg.br/ proposicoesWeb/fichadetramitacao?idProposicao=2141402. Acesso em 21 nov. 2019. p. 3-4.

${ }^{36}$ BRASIL. Câmara dos Deputados. Projeto de Lei 8.219/2017. Dispõe sobre a violência obstétrica praticada por médicos e/ou profissionais de saúde contra mulheres em trabalho de parto ou logo após. Brasília: Presidência da República, 2017b. Disponível em: http://www.camara.leg.br/proposicoesWeb/fichadetramitacao?idProposicao=2147144. Acesso em 21 nov. 2019.

${ }^{37}$ BRASIL. Câmara dos Deputados. Projeto de Lei 7.633/2014. Dispõe sobre a humanização da assistência à mulher e ao neonato durante o ciclo gravídico-puerperal e dá outras providências. Brasília: Presidência da República, 2014. Disponível em: http://www.camara.leg.br/proposicoesWeb/fichadetramitacao? idProposicao=617546\&ord=1. Acesso em 21 nov. 2019.

${ }^{38}$ BRASIL. Câmara dos Deputados. Projeto de Lei 6.888/2013. Altera a Lei no 8.069, de 13 de julho de 1990, que "dispõe sobre o Estatuto da Criança e do Adolescente e dá outras providências". Brasília: Presidência da República, 2013c. Disponível em: https://www.camara.leg.br/proposicoesWeb/fichadetramitacao?idProposicao=603313. Acesso em 09 ago. 2020.
} 
tratam da humanização da assistência à mulher e ao neonato (PL n ${ }^{\circ}$ 878/2019), da Política Nacional de Atendimento à Gestante (PL nº 2693/2019), da gravação de consultas pré-natais e parto (PL no 3310/2019) e, da opção por cesariana ou parto normal pela gestante (PL n ${ }^{\circ}$ $3635 / 2019)$.

Atualmente, os projetos supramencionados tramitam apensados ao PL n ${ }^{\circ} 6.567 / 2013$, o qual pretende alterar a Lei no 8.080/1990, relativa à prestação de serviços de saúde, de modo a estabelecer a obrigatoriedade do parto humanizado no Sistema Único de Saúde (SUS). No momento, tais proposições aguardam apreciação de Comissões. ${ }^{39}$ Em outro sentido, mencionase o PL $n^{\circ}$ 2589/2015, o qual pretende tornar a violência obstétrica como uma forma de constrangimento ilegal, crime disposto no art. 146, do Código Penal. Tal proposta aguarda parecer da Comissão de Seguridade Social e Família (CSSF). ${ }^{40}$

Embora não haja legislação específica a respeito de violência obstétrica no Congresso Nacional, algumas Assembleias Legislativas aprovaram leis sobre o assunto, como é o caso de Santa Catarina, Mato Grosso do Sul, Tocantins, Paraná, Pernambuco e Minas Gerais. Tais leis estaduais são bastante similares e coincidem ao listar as formas de cometimento da violência obstétrica, assim como mencionar que o autor dessas condutas está sujeito às sanções cabíveis. Apenas a lei paranaense menciona no que consistem tais sanções.

Com exceção da Lei n ${ }^{\circ} 23.175 / 2018$, de Minas Gerais ${ }^{41}$, os estados citados estabelecem em lei, a informação sobre violência obstétrica, por meio de cartazes e cartilha ou, apenas cartazes. A Lei $n^{\circ} 17.097 / 2017$, de Santa Catarina ${ }^{42}$; a Lei no $5.217 / 2018$, do Mato Grosso do

\footnotetext{
${ }^{39}$ BRASIL. Câmara dos Deputados. Projeto de Lei 6.567/2013. Altera o art. 19-J da Lei no 8.080, de 19 de setembro de 1990, que "dispõe sobre as condições para a promoção, proteção e recuperação da saúde, a organização e o funcionamento dos serviços correspondentes e dá outras providências", para incluir a obrigatoriedade de obediência às diretrizes e orientações técnicas e o oferecimento de condições que possibilitem a ocorrência do parto humanizado nos estabelecimentos de saúde do Sistema Único de Saúde (SUS). Brasília: Presidência da República, 2013d. Disponível em: https://www.camara.leg.br/proposicoesWeb/fichadetramitacao?idProposicao=596285\&ord=1. Acesso em 09 ago. 2020.

${ }^{40}$ BRASIL. Câmara dos Deputados. Projeto de Lei 2.589/2015. Dispõe sobre a criminalização da violência obstétrica. Brasília: Presidência da República, 2015. Disponível em: https://www.camara.leg.br/proposicoesWeb/fichadetramitacao?idProposicao=596285\&ord=1. Acesso em 09 ago. 2020.

${ }^{41}$ MINAS GERAIS. Lei ${ }^{\circ} 23.175$, de 21 de dezembro de 2018. Dispõe sobre a garantia de atendimento humanizado à gestante, à parturiente e à mulher em situação de abortamento, para prevenção da violência na assistência obstétrica no Estado. Disponível em: https://www.legisweb.com.br/legislacao/?id=372848. Acesso em: 12 dez. 2019.

${ }^{42}$ SANTA CATARINA. Lei $\mathrm{n}^{\circ}$ 17.097, de 17 de janeiro de 2017. Dispõe sobre a implantação de medidas de informação e proteção à gestante e parturiente contra a violência obstétrica no Estado de Santa Catarina. Disponível
} 
$\mathrm{Sul}^{43}$ e; a Lei $\mathrm{n}^{\mathrm{o}} 3.385 / 2018$, do Tocantins ${ }^{44}$ determinam que nesses cartazes conste a lista de condutas que configuram violência obstétrica. A Lei no 19.701/2018, do Paraná45, traz, em anexo, modelo de cartaz, que apenas menciona a existência da referida lei. A Lei $\mathrm{n}^{\circ}$ 16.499/2018, de Pernambuco ${ }^{46}$, estabelece que os cartazes informem: "Considera-se violência obstétrica todo ato praticado por profissionais de saúde, que implique em negligência na assistência, discriminação ou violência verbal, física, psicológica ou sexual contra mulheres gestantes, parturientes e puérperas".

As consequências da violência obstétrica escapam a defenições exatas, já que não há consenso sobre como realizar uma avaliação técnica com base no registro de ações que a configurem. Em função disto, uma das recomendações da OMS é que os governos apoiem pesquisas que tenham este propósito, de forma a permitir a compreensão de seu impacto. A Organização orienta para a promoção da conscientização sobre assistência obstétrica respeitosa, bem como o desenvolvimento de políticas, além de que o processo de eliminação da violência obstétrica conte com a participação das mulheres, comunidades, associações profissionais, organizações internacionais, entre outros. Além disso, destaca a necessidade de apoio social às mulheres nessa situação, inclusive, no que tange à ciência dos direitos e ao acesso à justiça. ${ }^{47}$

No entanto, mesmo cumprida a determinação acerca do acesso à justiça para a mulher vítima de violência obstétrica, importa a ressalva de que as ações sofridas por esta mãe têm potencial traumático perene, dada a carga emocional atrelada ao momento do parto. Além disto, tornando-se responsável por um filho (ou mais um filho), totalmente dependente, por um longo

em: http://www.leisestaduais.com.br/sc/lei-ordinaria-n-17097-2017-santa-catarina-dispoe-sobre-a-implantacaode-medidas-de-informacao-e-protecao-a-gestante-e-parturiente-contra-a-violencia-obstetrica-no-estado-de-santacatarina. Acesso em: 12 dez. 2019.

${ }^{43}$ MATO GROSSO DO SUL. Lei no 5.217, de 26 de junho de 2018. Dispõe sobre a implantação de medidas de informação e de proteção à gestante e à parturiente contra a violência obstétrica no Estado de Mato Grosso do Sul, e dá outras providências. Disponível em: https://www.legisweb.com.br/legislacao/?id=361631. Acesso em: 12 dez. 2019.

${ }^{44}$ TOCANTINS. Lei $\mathrm{n}^{\circ} 3.385$, de 27 de julho de 2018. Dispõe sobre a implementação de medidas de informação e proteção à gestante e parturiente contra a violência obstétrica no Estado do Tocantins. Disponível em: https://www.legisweb.com.br/legislacao/?id=365587. Acesso em: 09 ago. 2020.

45 PARANÁ. Lei $\mathrm{n}^{\circ} 19.701$ de 20 de novembro de 2018. Dispõe sobre a violência obstétrica, sobre direitos da gestante e da parturiente e revoga a Lei $n^{\circ} 19.207$, de $1^{\circ}$ de novembro de 2017, que trata da implantação de medidas de informação e proteção à gestante e à parturiente contra a violência obstétrica. Disponível em: https://www.legisweb.com.br/legislacao/?id=369582. Acesso em: 09 ago. 2020.

46 PERNAMBUCO. Lei $\mathrm{n}^{\circ}$ 16.499, de 06 de dezembro de 2018. Estabelece medidas de proteção à gestante, à parturiente e à puérpera contra a violência obstétrica, no âmbito do Estado de Pernambuco. Disponível em: https://www.legisweb.com.br/legislacao/?id=370732. Acesso em: 12 dez. 2019.

${ }^{47}$ ORGANIZAÇÃO MUNDIAL DA SAÚDE (OMS), 2014. 
período de tempo, a partir do nascimento. Neste cenário, é pouco provável que a mulher vítima de violência obstétrica tenha tempo ou disposição para litigar sobre seus direitos violados.

Isso decorre da supervalorização e romantização da maternidade. Ser mãe é colocado como um fenômeno capaz de superar qualquer inconveniente que a maternidade possa gerar e, ainda, representa uma quase obrigatoriedade para as mulheres, como se as compusesse. A mulher que não é mãe nem pretende ter filhos, frequentemente, é demandada a justificar-se, como se tal circunstância fosse antinatural. Além disso, atualmente, atribui-se o cuidado dos filhos, de forma significativamente mais densa, à mulher, muito embora não possa dedicar-se, integralmente, a essa tarefa, por mais árdua que seja. A maternidade é, além de tudo, financeiramente custosa, de forma que as mães, dificilmente, possam prescindir de um trabalho remunerado, com acúmulo dessas responsabilidades, o que esgota, mais facilmente, o tempo e a disposição.

Essas questões culturais e materiais dificultam o acesso à justiça, apesar da informação apropriada e acesso formal à vítima. Com isso, compatibiliza-se o fato de essas situações serem objeto de ação civil pública, de autoria do MPF e MP-AM, a qual reúne casos de dezenas de mulheres vítimas desse tipo de violência. Detalhes a respeito serão apresentados no próximo tópico.

\section{AÇÃO CIVIL PÚBLICA NO ENFRENTAMENTO DA VIOLÊNCIA OBSTÉTRICA}

Para ilustrar as possibilidades da ação civil pública para o combate da violência obstétrica cita-se, como exemplo, petição inicial da ação promovida pelo MPF, juntamente com o MP-AM ${ }^{48}$. Tal escolha justifica-se pelo nível de clareza da petição ao expor a trajetória percorrida até a propositura da ação, bem como pela robusta fundamentação exposta, elementos que a tornam didática e, portanto, adequada aos fins pretendidos neste estudo. Essa ação foi

48 AMAZONAS. Justiça Federal - Seção Judiciária do Amazonas. Ação civil pública $n^{\circ}$ 100541382.2018.4.01.3200. $3^{\text {a }}$ Vara Federal no Amazonas. Autores: Ministério Público do Estado do Amazonas (MPAM); Ministério Público Federal (MPF). Réus: Estado do Amazonas; União Federal. 28 nov. 2018. Disponível em: http://www.mpf.mp.br/am/sala-de-imprensa/docs/acp-violencia-obstetrica. Acesso em: 21 nov. 2019. 
proposta em 28 de novembro de 2018, a partir de representação ao MPF, por parte de Gabriela Repolho de Andrade, que relata abusos sofridos no nascimento de sua filha, em 2012.

Tal representação, apresentada em 2014, ensejou uma série de ações por parte do MPF e do MP-AM, as quais culminaram na ação civil pública que tramita na Justiça Federal do Amazonas, sob o $\mathrm{n}^{\circ}$ 1005413-82.2018.4.01.3200, sendo promovidas audiências públicas, reuniões com médicos, enfermeiros e universidades, bem como requisições de informações a maternidades. Portanto, antes do ajuizamento da petição a ser analisada, promoveram-se vários eventos a fim de esclarecer e verificar a ocorrência de violência obstétrica nos hospitais de Manaus.

Esta ação civil pública surge de casos de violência obstétrica que acabaram por ensejar a busca pela obrigação do Estado em incluir cláusula de combate à violência obstétrica em contratos, garantindo o direito das mulheres ao tratamento humanizado previsto na legislação brasileira. A ação, também, busca às usuárias, a disponibilização de canais efetivos para denúncias, além da apuração de eventuais casos de violência obstétrica registrados na Secretaria de Estado de Saúde (Susam) e finalização em tempo adequado. A ação civil pública requer, ainda, pedido de condenação para que o Amazonas e a União paguem danos morais coletivos no montante de $\mathrm{R} \$ 1$ milhão de reais, como o objetivo de ressarcir os danos ocasionados às mulheres em situação de violência obstétrica no estado do Amazonas.

Nessa ação civil pública foram confirmadas as diretrizes acerca da assistência humanizada ao parto $^{49}$, de caráter vinculante, as quais não eram, plenamente, cumpridas. Um exemplo é o caso das salas do Centro de Parto Normal da Maternidade Balbina Mestrinho: com capacidade para receber três parturientes por dia, sendo realizados apenas dez partos no período de um mês.

Em resumo, uma coisa foi possível verificar: por questões atécnicas e totalmente alheias ao melhor interesse das mulheres atendidas naquela oportunidade de maternidade, utilização de era um negado espaço às que pacientes poderia a lhes proporcionar acesso a instrumentos capazes de lhes garantir maior conforto e bem estar. Enquanto as salas do Centro de Parto Normal estavam vazias, durante a inspeção

\footnotetext{
${ }^{49}$ BRASIL. Ministério da Saúde. Secretaria de Ciência, Tecnologia e Insumos Estratégicos. Diretrizes nacionais de assistência ao parto normal: versão resumida. Brasília: Ministério da Saúde, 2017c. Disponível em: http://conitec.gov.br/images/Protocolos/Diretrizes/Diretrizes_PartoNormal_VersaoReduzida_FINAL.pdf. Acesso em: 29 mar. 2020.
} 
a sala de triagem do hospital estava com significativa lotação e as parturientes, enquanto em observação, sentavam-se em cadeiras nada confortáveis. ${ }^{50}$

Entre os motivos dos atos de violência cometidos, foram constatadas situações que não guardavam relação com a assistência em saúde, precisamente, com o atendimento à parturiente. Um dos exemplos apontados refere-se à urgência em desincumbir-se do atendimento próximo ao horário de troca de plantão. Outra circunstância consiste na divergência entre médicos e enfermeiros em relação aos procedimentos associados ao parto, o que demonstra uma competição pelo protagonismo profissional da situação, visto que técnicas de parto humanizado, atualmente em ascensão, frequentemente, exigem profissionais da enfermagem para conduzir o processo, o que pode ocasionar confusão de competências em relação aos(às) obstetras.

\begin{abstract}
Outra questão que foi trazida nesta primeira roda de conversa foi relacionada à suposta briga por mercado que seria o pano de fundo de todo o movimento de humanização do parto e combate à violência obstétrica no Amazonas. De acordo com o narrado durante a roda de conversa e ao longo da inspeção ministerial que lhe seguiu, a luta pelo nascimento humanizado e contra a violência obstétrica, na verdade, buscaria a ascensão da enfermagem obstétrica em detrimento da especialidade médica obstétrica. Sem prejuízo de se considerar o informado na formação de sua convicção, o que o Ministério Público verificou foi a resistência dos profissionais médicos trabalharem com os profissionais da enfermagem como uma equipe $[\ldots] .^{51}$
\end{abstract}

Os proponentes desta ação civil pública, anterior ao ajuizamento, apresentaram projeto básico com as obrigações aos contratados pelo Estado para a prestação de serviços de obstetrícia em maternidades públicas, com a finalidade de promover a alteração dos contratos. Os dispositivos incluídos no projeto estavam em consonância com recomendações da OMS e com evidências científicas estudadas pela Comissão Nacional de Incorporação de Tecnologias do Sistema Único de Saúde (CONITEC), mencionadas na Diretriz de Assistência ao Parto Normal, de 2016. Além disto, existem políticas em prol da humanização do parto no Brasil, as quais advogam pela "priorização do uso da tecnologia apropriada, pela qualidade da interação entre parturiente e seus cuidadores e pela desincorporação de tecnologia danosa". ${ }^{52}$ Por isto, os autores da ação afirmam que suas requisições eram bastante razoáveis.

Com efeito, destacam-se, entre estas orientações, as indicações de não administrar substâncias ou realizar procedimentos em casos não essenciais e de preencher, correta e cuidadosamente, os formulários necessários, ambas de evidente simplicidade. Em casos de

\footnotetext{
${ }^{50}$ AMAZONAS, 2018, p. 17.

${ }^{51}$ Ibid., p. 15.

52 Ibid., p. 47.
} 
maternidades que abriguem atividades escolares, atreladas às universidades, recomendam-se, ainda, cuidados para que o evento do parto não sirva, prioritariamente, ao ensino, em detrimento de condição de saúde e bem-estar da parturiente e do bebê. Tais cuidados são traduzidos na não-repetição de procedimentos apenas para fins didáticos, na garantia de que o ingresso de alunos na sala de parto não impeça a presença de acompanhante indicado pela parturiente e, o que sequer deveria precisar ser objeto de recomendação, na exigência de consentimento da paciente para qualquer dessas práticas.

Das orientações propostas, a mais drástica seria o imediato afastamento do profissional denunciado pela prática de violência obstétrica, sem prejuízo de processo administrativo para apuração da pertinência da acusação, com garantia do restabelecimento da posição no caso daquela não restar comprovada. No entanto, a resistência das empresas contratadas não estava adstrita a essa questão, tendo sido rechaçadas, também, as outras recomendações, quando das tratativas entre o Estado do Amazonas e a empresa que presta os serviços de medicina obstétrica.

\footnotetext{
A resistência da contratada não se limitou ao suposto rigor do afastamento sumário de profissionais que tenham comportamento não coerente com as diretrizes e normas que regem o Sistema Único de Saúde: todas as cláusulas relacionadas à assistência ao parto e ao nascimento humanizado foram rechaçadas pela empresa. ${ }^{53}$
}

A alegação da empresa para a negativa de acolhimento das outras disposições baseia-se no fato de tratar-se de conhecimento técnico especializado, de forma que não caberia ao Judiciário, ou mesmo ao contratante, o Estado do Amazonas, determiná-las. Contudo, os requisitantes relembram que essas orientações estão contempladas em documentos aprovados pelo Ministério da Saúde, detentor da autoridade técnica relativa à temática. Assim, conclui-se que trata-se de discussão jurídica que justifica o ajuizamento de ação para solução da demanda.

\footnotetext{
Portanto, fácil aferir que a discussão aqui é jurídica: é legítimo que uma empresa contratada pelo Estado se negar a cumprir diretrizes e normas nacionais de altíssima relevância pública por meio de um instrumento negocial? É legítimo o Poder Público renunciar a direitos dos usuários de seus serviços públicos?

Ao adotar tal postura resignada, o Estado anui com as condutas praticadas, afastandose de seu dever de bem prestar serviços de saúde e olvidando-se de que dispõe de outros meios para garantir o funcionamento de suas atividades, sendo o concurso público e a publicação de edital nacional para a contratação de profissionais, por exemplo, instrumentos para a quebra de monopólio da empresa hoje contratada. ${ }^{54}$
}

\footnotetext{
${ }^{53}$ AMAZONAS, 2018, p. 33.

${ }^{54}$ Ibid., p. 35.
} 
O MPF e o MP-AM, na fundamentação, destacam os motivos que justificam o ajuizamento da demanda em face da União, além do Estado do Amazonas, diretamente responsável pelas maternidades em que ocorreram as situações denunciadas. Os órgãos salientam que, apesar da descentralização preconizada pela Lei ${ }^{\circ}$ 8.080/1990, que trata da promoção da saúde e funcionamento dos serviços relacionados, a responsabilidade é solidária entre os entes federados. ${ }^{55}$ Portanto, tal descentralização não exclui a União da responsabilidade pelas ocorrências mencionadas na ação. Isto também define a competência da Justiça Federal para o caso, conforme dispõe o art. 109, I, da Constituição Federal. ${ }^{56}$

A ação argumenta que a violência combatida é baseada no gênero, demonstrada pela compreensão histórica do papel da mulher e do parto. Inicialmente, a proibição de mecanismos que busquem o alívio do sofrimento decorrente do parto, o qual concerne à compreensão religiosa de que a mulher é responsável pelo pecado original. Mais tarde, independente da culpa atribuída pela Igreja à mulher, compreendia-se que as condições adversas do parto colocavamna como vítima de sua natureza, o que autorizava o(a) obstetra a decidir, livremente, os procedimentos necessários para antecipar e combater os perigos do parto. Alguns desses procedimentos, serviam para afirmar a superioridade do(a) obstetra em relação às parteiras, apagando as práticas ora substituídas. ${ }^{57}$

Além destas questões históricas, o tratamento dispensado às parturientes, com desqualificação de suas falas e desconsideração de suas necessidades, conforme denunciado na petição, indicam o viés de gênero verificado nas condutas que caracterizam a violência obstétrica.

Diante destas considerações, com base na Constituição Federal e na Lei no 7.347/1985, os autores da petição requerem indenização, em virtude de dano moral coletivo. Ainda, fundamentando-se no Código de Processo Civil, solicitam tutela provisória de evidência, consistente em providências imediatas quanto ao atendimento realizado nas maternidades

\footnotetext{
${ }^{55}$ BRASIL. Lei ${ }^{\circ}$ 8.080, de 19 de setembro de 1990. Dispõe sobre as condições para a promoção, proteção e recuperação da saúde, a organização e o funcionamento dos serviços correspondentes e dá outras providências. Brasília: Presidência da República, 1990b. Disponível em: http://www.planalto.gov.br/ccivil_03/leis/18080.htm. Acesso em: 12 dez. 2019.

${ }^{56}$ BRASIL. Constituição da República Federativa do Brasil de 1988. Promulgada em 05 de outubro de 1988. Brasília: Presidência da República, 1988. Disponível em: http://www.planalto.gov.br/ccivil_03/constituicao/constituicaocompilado.htm. Acesso em: 12 dez. 2019.

57 AMAZONAS, 2018, p. 46.
} 
públicas do Amazonas, para que obedeça às normativas nacionais e internacionais vigentes. A petição analisada encontra-se, no momento, em fase de audiência de conciliação.

\section{CONSIDERAÇÕES FINAIS}

A leitura da petição inicial da ação civil pública em estudo demonstra que os motivos que levam aos atos de violência obstétrica são, frequentemente, alheios às necessidades médicas associadas ao parto, motivo pelo qual se mostra necessária à intervenção do Judiciário, por meio do Ministério Público para lidar com a problemática. Conforme constatado, a questão escapa à seara técnica da Medicina e constitui-se em questão jurídica, além traduz desobediência às normas técnicas expedidas pelas autoridades competentes, nacionais e internacionais, como o Ministério da Saúde e a OMS.

Para além do âmbito jurídico, observa-se que, em termos práticos, importa que haja legitimidade para interceder em prol da coletividade de gestantes e de parturientes submetidas à violência obstétrica. De acordo com as considerações apresentadas neste estudo, estas mulheres, muitas das quais tornaram-se mães, normalmente, não dispõem de condições emocionais e materiais para requerer reparação quanto ao dano que sofreram em função do trauma a que foram submetidas e das obrigações que passam no parto. Em específico, quanto às condições materiais, importa enfatizar que não se exaure em questões financeiras, mas, também, à disponibilidade de tempo exigida por qualquer litígio. Ainda, convém mencionar que, também, depende de informação acerca de seus direitos às vítimas.

Por fim, destaca-se a caracterização da violência obstétrica como forma de violência contra a mulher, não restrito, apenas, ao fato de que a mulher é capaz de engravidar e parir, mas em virtude da problemática de gênero que atravessam as condutas de quem pratica atos de violência, bem como o comportamento da vítima. Culturalmente, atribui-se à mulher responsabilidade, praticamente exclusiva, pela gravidez, o que implica na aceitação de riscos e consequências. 
Embora isso ocorra, inclusive, com gestações que decorram de um planejamento familiar, observa-se um agravamento no caso de gestações não planejadas. $\mathrm{O}$ controle do corpo feminino proíbe o prazer devendo servir ao homem e à família, de forma que estar em situação de violência obstétrica, em decorrência de uma gravidez fora de um casamento, é colocado como uma escolha da vítima, que então perde o direito de exigir tratamento com dignidade. Conforme relatado na petição, o mesmo ocorre com mulheres desviantes do comportamento "padronizado" como, por exemplo, usuárias de drogas. Assim, torna-se evidente que a problemática atinge não apenas as parturientes que passaram por tal experiência, mas a própria condição de ser mulher.

A percepção de que a violência obstétrica é uma forma de violência contra a mulher, a vulnerabilidade experimentada no puerpério e, mesmo posteriormente, na maternidade, além dos compromissos assumidos pelo Estado em relação à temática, indicam a pertinência da ação civil pública $\mathrm{n}^{\circ}$ 1005413-82.2018.4.01.3200, no combate às práticas violentas, cuja perpetuidade é inadmissível na sociedade contemporânea.

\section{REFERÊNCIAS BIBLIOGRÁFICAS}

AMAZONAS. Justiça Federal - Seção Judiciária do Amazonas. Ação civil pública $n^{\circ}$ 100541382.2018.4.01.3200. $3^{\text {a }}$ Vara Federal no Amazonas. Autores: Ministério Público do Estado do Amazonas (MP-AM); Ministério Público Federal (MPF). Réus: Estado do Amazonas; União Federal. 28 nov. 2018. Disponível em: http://www.mpf.mp.br/am/sala-de-imprensa/docs/acpviolencia-obstetrica. Acesso em: 21 nov. 2019.

ARENHART, Sérgio Cruz; MARINONI, Luiz Guilherme; MITIDIERO, Daniel. Novo curso de processo civil: tutela dos direitos mediante procedimentos diferenciados. v. 3. 2. ed. São Paulo: Revista dos Tribunais, 2016.

BENJAMIN, Antônio Herman V. A insurreição da aldeia global contra o processo civil clássico. Apontamentos sobre a opressão e a libertação judiciais do meio ambiente e do consumidor. In: MILARÉ, Édis (coord.). Ação civil pública. Lei 7.347/85 - reminiscências e reflexões após dez anos de aplicação. São Paulo: Revista dos Tribunais, 1995.

BRASIL. Câmara dos Deputados. Projeto de Lei 2.589/2015. Dispõe sobre a criminalização da violência obstétrica. Brasília: Presidência da República, 2015. Disponível em: 
https://www.camara.leg.br/proposicoesWeb/fichadetramitacao?idProposicao=596285\&ord=1. Acesso em 09 ago. 2020.

BRASIL. Câmara dos Deputados. Projeto de Lei 6.567/2013. Altera o art. 19-J da Lei no 8.080, de 19 de setembro de 1990, que "dispõe sobre as condições para a promoção, proteção e recuperação da saúde, a organização e o funcionamento dos serviços correspondentes e dá outras providências", para incluir a obrigatoriedade de obediência às diretrizes e orientações técnicas e o oferecimento de condições que possibilitem a ocorrência do parto humanizado nos estabelecimentos de saúde do Sistema Único de Saúde (SUS). Brasília: Presidência da República, 2013d. Disponível em: https://www.camara.leg.br/proposicoesWeb/fichadetramitacao?idProposicao=596285\&ord=1. Acesso em 09 ago. 2020.

BRASIL. Câmara dos Deputados. Projeto de Lei 6.888/2013. Altera a Lei n 8.069, de 13 de julho de 1990, que "dispõe sobre o Estatuto da Criança e do Adolescente e dá outras providências". Brasília: Presidência da República, 2013c. Disponível em: https://www.camara.leg.br/proposicoesWeb/fichadetramitacao?idProposicao=603313. Acesso em 09 ago. 2020.

BRASIL. Câmara dos Deputados. Projeto de Lei 7.633/2014. Dispõe sobre a humanização da assistência à mulher e ao neonato durante o ciclo gravídico-puerperal e dá outras providências. Brasília: Presidência da República, 2014. Disponível em: http://www.camara.leg.br/proposicoesWeb/fichadetramitacao?idProposicao=617546\&ord=1. Acesso em 21 nov. 2019.

BRASIL. Câmara dos Deputados. Projeto de Lei 7.867/2017. Dispõe sobre medidas de proteção contra a violência obstétrica e de divulgação de boas práticas para a atenção à gravidez, parto, nascimento, abortamento e puerpério. Brasília: Presidência da República, 2017a. Disponível em: https://www.camara.leg.br/proposicoesWeb/fichadetramitacao?idProposicao=2141402. Acesso em 21 nov. 2019.

BRASIL. Câmara dos Deputados. Projeto de Lei 8.219/2017. Dispõe sobre a violência obstétrica praticada por médicos e/ou profissionais de saúde contra mulheres em trabalho de parto ou logo após. Brasília: Presidência da República, 2017b. Disponível em: http://www.camara.leg.br/proposicoesWeb/fichadetramitacao?idProposicao=2147144. Acesso em 21 nov. 2019.

BRASIL. Constituição da República Federativa do Brasil de 1988. Promulgada em 05 de outubro de 1988. Brasília: Presidência da República, 1988. Disponível em: http://www.planalto.gov.br/ccivil_03/constituicao/constituicaocompilado.htm. Acesso em: 12 dez. 2019.

BRASIL. Decreto $\mathrm{n}^{\circ} 1.973$, de 01 de agosto de 1996. Promulga a Convenção Interamericana para Prevenir, Punir e Erradicar a Violência contra a Mulher, concluída em Belém do Pará, em 9 de junho de 1994. Brasília: Presidência da República, 1996. Disponível em: http://www.planalto.gov.br/ccivil_03/decreto/1996/D1973.htm. Acesso em: 06 dez. 2019.

BRASIL. Decreto $n^{\circ} 4.377$, de 13 de setembro de 2002. Promulga a Convenção sobre a Eliminação de Todas as Formas de Discriminação contra a Mulher, de 1979, e revoga o Decreto 
no 89.460, de 20 de março de 1984. Brasília: Presidência da República, 2002. Disponível em: http://www.planalto.gov.br/ccivil_03/decreto/2002/D4377.htm. Acesso em: 06 dez. 2019.

BRASIL. Decreto $\mathrm{n}^{\mathrm{o}}$ 5.017, de 12 de março de 2004. Promulga o Protocolo Adicional à Convenção das Nações Unidas contra o Crime Organizado Transnacional Relativo à Prevenção, Repressão e Punição do Tráfico de Pessoas, em Especial Mulheres e Crianças. Brasília: Presidência da República, 2004. Disponível em: http://www.planalto.gov.br/ccivil_03/_Ato2004-2006/2004/Decreto/ D5017.htm. Acesso em: 06 dez. 2019.

BRASIL. Decreto $\mathrm{n}^{\circ} 7.958$, de 13 de março de 2013. Estabelece diretrizes para o atendimento às vítimas de violência sexual pelos profissionais de segurança pública e da rede de atendimento do Sistema Único de Saúde. Brasília: Presidência da República, 2013b. Disponível em: http://www.planalto.gov.br/ccivil_03/_ato2011-2014/2013/decreto/D7958.htm. Acesso em: 30 nov. 2019.

BRASIL. Decreto-Lei no 2.848, de 07 de dezembro de 1940. Código Penal. Rio de Janeiro: Presidência da República, 1940. Disponível em: http://www.planalto.gov.br/ccivil_03/decretolei/Del2848.htm. Acesso em: 24 nov. 2019.

BRASIL. Lei $\mathrm{n}^{\circ} 11.340$, de 07 de agosto de 2006. Cria mecanismos para coibir a violência doméstica e familiar contra a mulher, nos termos do $\S 8^{\circ}$ do art. 226 da Constituição Federal, da Convenção sobre a Eliminação de Todas as Formas de Discriminação contra as Mulheres e da Convenção Interamericana para Prevenir, Punir e Erradicar a Violência contra a Mulher; dispõe sobre a criação dos Juizados de Violência Doméstica e Familiar contra a Mulher; altera o Código de Processo Penal, o Código Penal e a Lei de Execução Penal; e dá outras providências. Brasília: Presidência da República, 2006. Disponível em: http://www.planalto.gov.br/ccivil_03/leis/L9455.htm. Acesso em: 24 nov. 2019.

BRASIL. Lei $\mathrm{n}^{\circ} 12.845$, de 01 de agosto de 2013. Dispõe sobre o atendimento obrigatório e integral de pessoas em situação de violência sexual. Brasília: Presidência da República, 2013a. Disponível em: http://www.planalto.gov.br/ ccivil_03/_ato2011-2014/2013/lei/112845.htm. Acesso em: 21 set. 2019.

BRASIL. Lei $\mathrm{n}^{\circ}$ 7.347, de 24 de julho de 1985. Disciplina a ação civil pública de responsabilidade por danos causados ao meio-ambiente, ao consumidor, a bens e direitos de valor artístico, estético, histórico, turístico e paisagístico (VETADO) e dá outras providências. Brasília: Presidência da República, 1985. Disponível em: http://www.planalto.gov.br/ccivil_03/Leis/L7347Compilada.htm. Acesso em: 13 dez. 2019.

BRASIL. Lei no 8.078, de 11 de setembro de 1990. Dispõe sobre a proteção do consumidor e dá outras providências (Código de Defesa do Consumidor). Brasília: Presidência da República, 1990a. Disponível em: http://www.planalto.gov.br/ccivil03/leis/18078.htm. Acesso em: 12 dez. 2019.

BRASIL. Lei ${ }^{\circ}$ 8.080, de 19 de setembro de 1990. Dispõe sobre as condições para a promoção, proteção e recuperação da saúde, a organização e o funcionamento dos serviços correspondentes e dá outras providências. Brasília: Presidência da República, 1990b. Disponível em: http://www.planalto.gov.br/ccivil_03/leis/18080.htm. Acesso em: 12 dez. 2019. 
BRASIL. Ministério da Saúde. Secretaria de Atenção à Saúde. Despacho DAPES/SAS/MS em resposta a Ofício no 017/2019 JUR/SEC. Brasil: Ministério da Saúde, 03 maio 2019. 2019a. Disponível https://sei.saude.gov.br/sei/controlador_externo.php?acao=documento_conferir\&codigo_verif icador $=9087621 \&$ codigo_crc=1A6F34C4\&hash_download $=c 4 c 55 \mathrm{~cd} 95$ ede706d0b729845a5d 6481d07e735f33d87d40984dd1b39a32d870fe89dcf1014bc76a32d2a28d8f0a2c5ab928ff165c 67d8219e35beb1a0adb3258\&visualizacao=1\&id_orgao_acesso_externo=0. Acesso em: 12 nov. 2019.

BRASIL. Ministério da Saúde. Secretaria de Atenção Primária à Saúde. Ofício 296/2019/COSMU/CGCIVI/DAPES/SAPS/MS. Brasil: Ministério da Saúde, 07 jun. 2019. 2019b. Disponível em: http://www.mpf.mp.br/sp/sala-de-imprensa/docs/oficio-ms. Acesso em: 12 nov. 2019.

BRASIL. Ministério da Saúde. Secretaria de Ciência, Tecnologia e Insumos Estratégicos. Diretrizes nacionais de assistência ao parto normal: versão resumida. Brasília: Ministério da Saúde, 2017c. Disponível em: http://conitec.gov.br/images/Protocolos/Diretrizes/Diretrizes_PartoNormal_VersaoReduzida_ FINAL.pdf. Acesso em: 29 mar. 2020.

FUNDAÇÃO PERSEU ABRAMO (FPA); SERVIÇO SOCIAL DO COMÉRCIO (SESC). Mulheres brasileiras e gênero nos espaços público e privado. ago. 2010. Disponível em: https://fpabramo.org.br/publicacoes/wp-content/uploads/sites/5/2017/05/pesquisaintegra0.pdf. Acesso em: 21 nov. 2019.

GRECO, Rogério. Direito Penal Estruturado. Rio de Janeiro: Forense, 2019.

JARDIM, Danúbia Mariane Barbosa; MODENA, Celina Maria. A violência obstétrica no cotidiano assistencial e suas características. Revista Latino-Americana Enfermagem. 2018. v. 26. Disponível em: http://www.scielo.br/pdf/rlae/v26/pt_0104-1169-rlae-26-e3069.pdf. Acesso em: 12 nov. 2019.

MATO GROSSO DO SUL. Lei n ${ }^{\circ}$ 5.217, de 26 de junho de 2018. Dispõe sobre a implantação de medidas de informação e de proteção à gestante e à parturiente contra a violência obstétrica no Estado de Mato Grosso do Sul, e dá outras providências. Disponível em: https://www.legisweb.com.br/legislacao/?id=361631. Acesso em: 12 dez. 2019.

MERCOSUL. Guia Mercosul de atenção a mulheres em situação de tráfico de pessoas para fins de exploração sexual. dez. 2012. Disponível em: https://www.unodc.org/documents/human-trafficking/GLO-

ACT/BR_Guia_MERCOSUL_Trafico_Mulheres_PORT_Completo_para_IMPRESSAO.pdf. Acesso em: 13 jan. 2020.

MINAS GERAIS. Lei $\mathrm{n}^{\mathrm{o}}$ 23.175, de 21 de dezembro de 2018. Dispõe sobre a garantia de atendimento humanizado à gestante, à parturiente e à mulher em situação de abortamento, para prevenção da violência na assistência obstétrica no Estado. Disponível em: https://www.legisweb.com.br/legislacao/?id=372848. Acesso em: $12 \mathrm{dez} .2019$. 
MINISTÉRIO PÚBLICO FEDERAL (MPF). Recomendação $n^{\circ}$ 29/2019. São Paulo (Estado): Ministério Público Federal, 07 maio 2019. Disponível em: http://www.mpf.mp.br/sp/sala-deimprensa/docs/recomendacao_ms_violencia_obstetrica.pdf. Acesso em: 12 nov. 2019.

MORIN, Edgar. Introdução ao Pensamento Complexo. 5. ed. Porto Alegre: Sulina, 2015.

ORGANIZAÇÃO DAS NAÇÕES UNIDAS (ONU). Declaração do Milênio. Nova Iorque, 2000. Disponível em: https://www.br.undp.org/content/brazil/pt/home/library/ods/declaracaodo-milenio.html. Acesso em: 20 mar. 2020.

ORGANIZAÇÃO DAS NAÇÕES UNIDAS (ONU). Declaração e Plataforma de Ação da IV Conferência Mundial Sobre a Mulher. Pequim, 1995. Disponível em: http://www.onumulheres.org.br/wp-content/uploads/2015/03/declaracao_pequim1. pdf. Acesso em: 06 set. 2019.

ORGANIZAÇÃO DOS ESTADOS AMERICANOS (OEA). Declaração e Programa de Ação adotados na III Conferência Mundial de Combate ao Racismo, Discriminação Racial, Xenofobia e Intolerância Correlata. Durban, 08 set. 2001. Disponível em: https://www.oas.org/dil/port/2001\%20Declara\%C3\%A7\%C3\%A3o\%20e\%20Programa\%20d e\%20A\%C3\%A7\%C3\%A3o\%20adotado\%20pela\%20Terceira\%20Confer\%C3\%AAncia\%20 Mundial\%20contra\%20o\%20Racismo,\%20Discrimina\%C3\%A7\%C3\%A3o\%20Racial,\%20X enofobia\%20e\%20Formas\%20Conexas\%20de\%20Intoler\%C3\%A2ncia.pdf. Acesso em: 20 mar. 2020.

ORGANIZAÇÃO MUNDIAL DA SAÚDE (OMS). Prevenção e eliminação de abusos, desrespeito e maus-tratos durante o parto em instituições de saúde. 2014. Disponível em: https://apps.who.int/iris/bitstream/handle/10665/134588/ WHO_RHR_14.23_por.pdf. Acesso em: 21 nov. 2019.

PARANÁ. Lei $\mathrm{n}^{\circ} 19.701$ de 20 de novembro de 2018. Dispõe sobre a violência obstétrica, sobre direitos da gestante e da parturiente e revoga a Lei $n^{\circ} 19.207$, de $1^{\circ}$ de novembro de 2017, que trata da implantação de medidas de informação e proteção à gestante e à parturiente contra violência obstétrica. Disponível em: https://www.legisweb.com.br/legislacao/?id=369582. Acesso em: 09 ago. 2020.

PASINATO, Wânia. "Femicídios" e as mortes de mulheres no brasil. Cadernos Pagu, n. 37, p. 219-246, jul.-dez. 2011. Disponível em: https://www.scielo.br/pdf/cpa/n37/a08n37.pdf. Acesso em: 29 nov. 2019.

PERNAMBUCO. Lei n ${ }^{\circ}$ 16.499, de 06 de dezembro de 2018. Estabelece medidas de proteção à gestante, à parturiente e à puérpera contra a violência obstétrica, no âmbito do Estado de Pernambuco. Disponível em: https://www.legisweb.com.br/legislacao/?id=370732. Acesso em: 12 dez. 2019.

SANTA CATARINA. Lei n 17.097, de 17 de janeiro de 2017. Dispõe sobre a implantação de medidas de informação e proteção à gestante e parturiente contra a violência obstétrica no Estado de Santa Catarina. Disponível em: http://www.leisestaduais.com.br/sc/lei-ordinaria-n17097-2017-santa-catarina-dispoe-sobre-a-implantacao-de-medidas-de-informacao-e- 
protecao-a-gestante-e-parturiente-contra-a-violencia-obstetrica-no-estado-de-santa-catarina. Acesso em: 12 dez. 2019.

TOCANTINS. Lei $\mathrm{n}^{\circ} 3.385$, de 27 de julho de 2018. Dispõe sobre a implementação de medidas de informação e proteção à gestante e parturiente contra a violência obstétrica no Estado do Tocantins. Disponível em: https://www.legisweb.com.br/legislacao/?id=365587. Acesso em: 09 ago. 2020.

Data de Submissão: 10/08/2020

Data de Aceite: 17/11/2020 